\title{
Fine-scale temporal dynamics of herpes virus and vibrios in seawater during a polymicrobial infection in the Pacific oyster Crassostrea gigas
}

\author{
Petton Bruno 1, De Lorgeril Julien 2, Mitta Guillaume 4, Daigle Gaétan 3, Pernet Fabrice 1, \\ Alunno Bruscia Marianne ${ }^{1, *}$
}

1 Ifremer, LEMAR UMR 6539 (Université de Bretagne Occidentale, CNRS, IRD, Ifremer), 11 presqu'île du Vivier, 29840 Argenton-en-Landunvez, France

2 IHPE Interaction Host Pathogen Environment, UMR 5244 (Ifremer, Université de Perpignan Via Domitia, CNRS, Université de Montpellier), CC 80, 34095 Montpellier, France

${ }^{3}$ service de Consultation Statistique (SCS), Département de mathématiques et de statistique, Pavillon Adrien-Pouliot, Université Laval, 1065 av. de la Médecine, Québec City, Québec G1V 0A6, Canada

* Corresponding author : Marianne Alunno Bruscia, email address : marianne.alunno.bruscia@ifremer.fr

\begin{abstract}
:
The Pacific oyster Crassostrea gigas is currently being impacted by a polymicrobial disease that involves early viral infection by ostreid herpesvirus-1 (OsHV-1) followed by a secondary bacterial infection leading to death. A widely used method of inducing infection consists of placing specific pathogen-free oysters ('recipients') in cohabitation in the laboratory with diseased oysters that were naturally infected in the field ('donors'). With this method, we evaluated the temporal dynamics of pathogen release in seawater and the cohabitation time necessary for disease transmission and expression. We showed that OsHV-1 and Vibrio spp. in the seawater peaked concomitantly during the first $48 \mathrm{~h}$ and decreased thereafter. We found that $1.5 \mathrm{~h}$ of cohabitation with donors was enough time to transmit pathogens to recipients and to induce mortality later, reflecting the highly contagious nature of the disease. Finally, mortality of recipients was associated with increasing cohabitation time with donors until reaching a plateau at $20 \%$. This reflects the cumulative effect of exposure to pathogens. The optimal cohabitation time was 5-6 d, the mortality of recipients occurring $1-2 \mathrm{~d}$ earlier.
\end{abstract}

Keywords : Aquaculture, bivalve, epidemiology, health, polymicrobial disease, OSHV-1, POMS 
Mortality outbreaks in Pacific oyster Crassostrea gigas associated with infection by

viral and bacterial pathogens have increased during the last 10 years worldwide (AHAW 2015, Barbosa Solomieu et al. 2015, Pernet et al. 2016). The most striking example is the massive mortality syndrome which affects oyster juveniles (Pacific Oyster Mortality Syndrome, POMS) killing up to $100 \%$ of the farmed oysters. These mortalities coincide with the recurrent detection of Ostreid herpesvirus-1 (OsHV-1) variants worldwide (Segarra et al. 2010, Lynch et al. 2012, Jenkins et al. 2013, Mortensen et al. 2016). However, other etiological agents such as virulent bacterial strains assigned to the genus Vibrio are systematically associated to diseased oysters (Petton et al. 2015b, de Lorgeril et al. 2018a).

The economic costs associated with increased mortality has led to a major research effort to improve the knowledge on POMS. This research requires a method of pathogenesis which retains the whole complexity of the pathosystem and follows the natural route of infection. These last objectives are not fully reached using experimental systems in which the studied oysters are directly injected with a purified suspension of pathogens (OsHV-1 or vibrios) or placed in cohabitation with injected oysters. Direct injection relies on one or two pathogens of interest, generally a virus (OsHV-1), a bacteria (from the Vibrio genus) or both (i.e. Schikorski et al. 2011, Azema et al. 2016), and does reflect neither the complexity of the infectious process nor the natural route of the infection. In addition, injection prevents the study of disease transmission. Cohabitation with injected oysters partly circumvents these problems. Recipient oysters placed in 64 cohabitation with injected donors are "naturally" infected, but the polymicrobial nature of the disease is not properly addressed. In addition, injection-based methods often 
require that the causative pathogen is well identified, isolated and cultivable or amplifiable, which may not be the case when diseases emerge.

To circumvent these issues, we used an experimental pathosystem in which specific pathogen-free recipient oysters (Le Roux et al. 2016) are placed in cohabitation in controlled conditions with diseased oysters (donors) that were naturally infected in the field when disease-induced mortalities were occurring (Petton et al. 2013). This method retains the whole complexity of pathogens (OsHV-1 and populations of virulent bacteria) and follows the natural route of infection.

This approach was successfully used to investigate disease risk factors such as seawater temperature (Petton et al. 2013, Pernet et al. 2015), salinity (Fuhrmann et al. 2016), pH (Fuhrmann et al. 2019), water renewal or biomass of infected hosts (Petton et al. 2015a), bacterial populations (Lemire et al. 2015, Bruto et al. 2017), toxic algae (Lassudrie et al. 2015) and physiological condition of oysters (Tamayo et al. 2014, Fuhrmann et al. 2018), while the dynamics, relative weights and interactions of the different aetiological agents were not clearly established. Since then, this method was applied to demonstrate that POMS is a polymicrobial infection in which a OsHV-1 creates an immune-compromised state of oysters evolving towards subsequent bacteraemia by opportunistic bacterial pathogens leading to oyster death (de Lorgeril et al. 2018b).

Although this experimental pathosystem has been widely used for the last 5 years, the dynamics of disease transmission through the water column remains to be characterized. In the present study, we evaluated the effect of the cohabitation time between donors and recipients on the mortality of recipients; we followed the temporal dynamics of OsHV-1 and Vibrio spp during the cohabitation phase in the seawater; and we tested the relationship between the cumulative exposure to these microorganisms and oyster mortality. As a corollary, we defined the required cohabitation time between 
donors and recipients to exhibit significant mortality and we drew practical consequences for both experimenters and growers.

\section{MATERIAL \& METHODS}

\section{Animal production and maintenance}

Donors were progenies of 15 biparental oyster families that were produced to the Ifremer facility at Argenton (Brittany, France) mid-March 2015 (de Lorgeril et al. 2018b). The parents originated from wild stocks collected in farming and non-farming areas (2 areas) in the Mediterranean Thau lagoon and in the Bay of Brest ( 2 sites), and from a mass selection programme to enhance their resistance to the mortality syndrome $(2$ areas $\times 2$ sites +1 selected $=5$ origins, 3 families for each origin) (de Lorgeril et al. 2018b). Recipients were progenies of wild oysters ( $\mathrm{n}=90$ individuals) collected in a farming-area in Marennes-Oléron (France) produced on 28 April 2015 as previously described (Petton et al. 2015a). These oysters were maintained free of specific pathogens (SPF) under controlled bio-secured conditions until the onset of the experiment. The specific pathogen-free status of donors and recipients was confirmed by the absence of OsHV-1 DNA detection by qPCR and a low level of Vibrio spp. ( 1 cfu $100 \mathrm{mg}^{-1}$ tissues, $\mathrm{n}=3$ pools of five individuals for donors and recipients) (Petton et al. 2015a, Le Roux et al. 2016).

This experiment was conducted at the Ifremer facility at Argenton in an area where seawater temperature is lower than $14.5^{\circ} \mathrm{C}$ and Pacific oyster is absent. Therefore OsHV1 is locally unexpected. However, controlled bio-secured conditions were maintained by filtrations and UV irradiation. The first treatment was applied after the pumping system (filtrations on $50-\mu \mathrm{m}$ lamellar filter, $10-\mu \mathrm{m}$ pocket filter and 1- $\mu \mathrm{m}$ glass-fibber filter; UVdevice COMAP Water Treatment V3 Pehd model, $250 \mathrm{~W}$ ). The second treatment was applied in the experimental room (filtration on 1- $\mu$ m glass-fibber filter, JBL ProCristal UV- 
116 C 18W). The bio-secured conditions were confirmed by monitoring daily the levels of

117 OsHV-1 DNA and Vibrio spp. in the seawater (see below for the protocol).

118 During the experiment, oysters were continuously supplied with treated seawater 119 at $21^{\circ} \mathrm{C}$ under a $24 \mathrm{~h}$ light cycle with a light aeration. Before the onset of the cohabitation 120 phase, seawater renewal in the oyster tanks was 50\% (i.e. half of the tank volume was 121 renewed within one hour). During the cohabitation phase, seawater renewal was lowered 122 at 5 to $10 \%$. Oxygen saturation was always $>95 \%$ and $\mathrm{pH}$ was between 7.9 and 8.2 which 123 are suitable life conditions for C. gigas. Oysters were continuously fed a mixed diet of 124 Tisochryis lutea and Chaetoceros muelleri (50:50, v/v) at 500 to $1000 \mu \mathrm{m}^{3} \mu \mathrm{L}^{-1}$ at the outlet 125 pipe of the tank. Temperature, salinity, $\mathrm{pH}$, oxygen and phytoplankton concentration were 126 measured each 12 hours with the WTW probes xi3101, cond340, pH3310 and FD0 925, 127 and the Coulter particle counter (Multisizer 3) respectively. Seawater effluents were 128 collected in a disposal tank and chlorinated for 2 hours (12 mg/L of free chlorine) before 129 neutralization with sodium thiosulfate $(20 \mathrm{mg} / \mathrm{L})$.

\section{Experimental cross-over design}

On 3 September 2015, part of a mixed population containing an equivalent biomass 133 of each oyster family (6.5-month-old, $1.4 \mathrm{~g}$ mean individual mass) was deployed in the 134 Thau lagoon for 17 days and further used as pathogen donors (Petton et al. 2013). During 135 this period, seawater temperature decreased from $23.9^{\circ} \mathrm{C}$ to $20.1^{\circ} \mathrm{C}$, which is permissive 136 for OsHV-1 infection (Pernet et al. 2012). Then they were brought back to the Ifremer 137 facility (Argenton, France) within 24 hours and immediately placed in a flow through 350138 L tank $(200 \times 70 \times 60 \mathrm{~cm})$, referred to as "pathogen-exposure tank". A subsample of the 139 donor population ( $\mathrm{n}=100$ individuals) was placed in mesh-bags $(25 \times 30 \times 1 \mathrm{~cm})$ for 140 regularly counting the dead. The remaining part of the mixed oyster population was left 
141 undisturbed at the facility and placed in another 350-L tank to be used as uninfected

142 control. The biomass of oysters in both the pathogen-exposure and the control tanks was

$1431800 \mathrm{~g}$, corresponding to $\mathrm{ca} .1000$ animals.

144 In the meantime, the non-exposed batch of SPF animals was dispatched in 51 mesh145 bags $(25 \times 30 \times 1 \mathrm{~cm})$ at an identical density per bag $(100 \pm 6$ individuals per bag, $1.1 \mathrm{~g}$ mean 146 individual mass). Seventeen bags were directly placed in the pathogen-exposure tank in 147 cohabitation with the donors and they were used as pathogen "recipients" (Petton et al. 148 2013). The biomass of donors equalled that of recipients. Seventeen other bags were 149 placed in individual flow through $50-\mathrm{L}$ tanks $(58 \times 38 \times 24 \mathrm{~cm})$ referred to as "safe tanks". 150 Then, each bag was either transferred from the pathogen-exposure towards safe tanks 151 (sequence 1) or from safe tanks towards the pathogen-exposure tank (sequence 2, Figure

152 1) according to a cross-over design (2 sequences $\times 2$ treatments; Jones \& Kenward 2014). 153 These permutations were conducted $1.5,3,6,12,24,36,48,60,72,88,110,125,150,172$, 154196 or 220 hours after the start of the cohabitation phase ( $\mathrm{n}=16$ permutation times). The 155 donors were removed from the pathogen-exposure tank after $220 \mathrm{~h}(9.2 \mathrm{~d})$. Two oyster 156 bags were left undisturbed in the pathogen-exposure tank and in one safe tank. Live and 157 dead recipients were counted $i$ ) at the permutation time in the relevant bags only and ii) 158 at the end of the experiment in each bag $391 \mathrm{~h}(16 \mathrm{~d})$ after the start of the cohabitation 159 phase. Also, live and dead donors and uninfected controls were counted at each 160 permutation time.

162 Quantification of OsHV-1 DNA and of Vibrio spp. The levels of OsHV-1 DNA and Vibrio spp. were determined $i$ ) in three pools of five 164 donors and three pools of five recipients sampled at the onset of field-exposure and in five 165 dead recipients sampled in the undisturbed bags in the pathogen-exposure tank $136 \mathrm{~h}$ 
after the beginning of the cohabitation phase; and ii) in seawater samples collected with sterile 15-mL Falcon tubes at the outlet in the pathogen-exposure tank and in the control safe tanks $0,1.5,3,6,9,12,15,21,24,28,32,36,40,44,48,54,60,72,80,88,96,110$, $125,150,160,172,196,220,232,244$ hours after the onset of cohabitation $(n=30$ sampling times). These analyses were conducted on aliquots of $200 \mu \mathrm{L}$ taken from two samples of $10 \mathrm{~mL}$ seawater. All samples were stored at $-20^{\circ} \mathrm{C}$.

For oysters, whole tissues were removed from the shells and homogenized in sterile artificial seawater. Total DNA was extracted from oyster and seawater samples with a QIAamp tissue mini kit (Qiagen) according to the manufacturer's protocol. The extracts were stored at $-20^{\circ} \mathrm{C}$ before detection and quantification according to a real-time PCR protocol based on SYBR Green chemistry (Pepin et al. 2008) with specific primers developed by Webb et al. (2007). The specificity and sensitivity of the detection test using these primers is similar to those reported by Pepin et al. (2008) (T. Renault pers. comm.). The method used in our study was the recommended method for reasons of availability, utility, and diagnostic specificity and sensitivity for OsHV-1 detection (OIE 2012, www.oie.int/fileadmin/Home/eng/Health_standards/aahm/2010/2.4.09_INF_OSTREID _ HERPES.pdf). The results were expressed as the log of OsHV-1 DNA copies per mL of seawater or per mg of wet oyster tissue. Virus detection and quantification analyses were conducted by Labocea, a French public diagnostic laboratory (Quimper, France), in compliance with approved quality management system ISO 17025 and COFRAC. In 2009 the OsHV-1 $\mu$ Var had fully replaced the reference OsHV-1 genotype in oysters presenting mortality at all French oyster production sites (Segarra et al. 2010, Martenot et al. 2011, Renault et al. 2012) and this was confirmed in infected oysters collected in 2015 (de Lorgeril et al. 2018b). We also performed dual RNA-Seq on oyster immersed in the same tank during the cohabitation and reads were mapped on the OsHV-1 $\mu$ Var. A genome 
(KY242785) (Lucasson et al. in preparation). In order to determine if oyster were infected by OsHV-1 or by OsHV-1 $\mu$ Var we looked at the expression of ORF IN.1, .2, .3 and .4 which

193

194 are only present in OsHV-1 $\mu$ Var (Burioli et al. 2017). We observed that reads mapping on IN.1 to .4 genes represent $0.37 \%$ of the total reads mapped on the viral genome strongly suggesting that oysters were infected by OsHV-1 $\mu$ Var. Therefore, in the present study we refer to 'OsHV-1' as 'OsHV-1 $\mu$ Var'.

Homogenate of oyster tissue samples diluted in sterilized seawater (1:10) and subsamples of seawater $(100 \mu \mathrm{L})$ were spread on thiosulfate-citrate-bile salts-sucrose (TCBS) agar in Petri dishes to quantify Vibrio spp. concentration. The plates were incubated at $21.0^{\circ} \mathrm{C}$ for $48 \mathrm{~h}$ before counting the number of colonies forming units (cfu). Results were expressed as cfu mg-1 of wet tissues in oysters and $c f u \mathrm{~mL}^{-1}$ in seawater samples. The study focused on total Vibrio load without knowing which species were present including pathogenic strains as it is a reliable indicator of the bacteraemia typical of POMS (Petton et al. 2015b, de Lorgeril et al. 2018b).

\section{Statistical analyses}

Regression models were used to examine the relationship between mortality of recipients $391 \mathrm{~h}$ after the onset of cohabitation and time of transfer from pathogenexposure toward safe tanks (sequence 1) and from safe toward pathogen-exposure tanks (sequence 2). Best fitted regression models were exponential growth and decay for sequence 1 and 2 respectively:

$$
\begin{array}{ll}
y(t)_{\text {seq } 1}=a_{0}\left(1-e^{-a 1 t}\right), & a_{0}>0, a_{1}>0 \\
y(t)_{\text {seq } 2}=b_{0} e^{-b 1 t}, & b_{0}>0, b_{1}>0
\end{array}
$$

Mortality reached a plateau at a for sequence 1 , and at 0 for sequence 2 since:

$$
\lim _{t \rightarrow \infty} y_{(t) \operatorname{seq} 1}=a_{0}
$$




$$
\lim _{t \rightarrow \infty} y_{(t) \operatorname{seq} 2}=0
$$

The increase in mortality became not significant at the point where the confidence interval of the slope reached 0 . To estimate this time point for the sequence 1 , the error calculated using the Delta method (Oehlert 1992) may be written as:

$$
y^{\prime}(t)_{s e q 1}=a_{0} a_{1} e^{-a_{1} t}
$$

$$
\begin{aligned}
& \operatorname{se}\left[y^{\prime}(t)_{\text {seq } 1}\right]=e^{-a_{1} t}\left\{a_{1}^{2} \operatorname{var}\left(a_{0}\right)+\left(a_{0}\left(1-a_{1} t\right)\right)^{2} \operatorname{var}\left(a_{1}\right)+2 a_{0} a_{1}(1-\right. \\
& \left.\left.a_{1} t\right) \operatorname{cov}\left(a_{0} a_{1}\right)\right\}^{1 / 2}
\end{aligned}
$$

Therefore, the $95 \%$ confidence interval of the slope was:

$$
y^{\prime}(t)_{\text {seq } 1} \pm 1.96 s e\left[y^{\prime}(t)_{s e q 1}\right]
$$

and the instantaneous rate of change of mortality is no longer significant when the lower limit of this interval is equal to 0 :

$$
y^{\prime}(t)_{s e q 1}-1.96 s e\left[y^{\prime}(t)_{s e q 1}\right]=0
$$

The same procedure (eq. 5 to 8) was applied to the data of sequence 2 using the upper limit of the interval for that case:

$$
y^{\prime}(t)_{\text {seq } 2}+1.96 s e\left[y^{\prime}(t)_{s e q 2}\right]=0
$$

Polynomial regression models were fitted to the temporal dynamics of OsHV-1 DNA and Vibrio spp. concentrations in seawater during the first $244 \mathrm{~h}$ after the onset of the 234 cohabitation phase. The independent variable (time) was centred at its mean $(\bar{t}=78.9 \mathrm{~h})$ 235 to reduce structural multicollinearity and converted in days. Also, OsHV-1 DNA was $236 \log _{10}\left(\mathrm{x} / 10^{6}+1\right)$ transformed and Vibrio spp. concentration was $\log _{10}(10 \mathrm{x}+1)$ transformed to meet the normality assumption.

To relate microorganism exposure to risk of death at some specified time point, exposure history was summarized into a single value that represents the total amount of 
exposure experienced up to that time (Vacek 1997). The metric most frequently used is

241 the "cumulative exposure index" which is a time-weighted summation of exposure

242 intensities. In our study, the CEI were calculated for OsHV-1 and Vibrio spp. and

243 corresponded to the areas under the polynomials between two time points $(a, b) \in[0,244]$

244 as: as:

$$
\begin{gathered}
\int_{t_{a}}^{t_{b}}\left(\alpha_{0}+\alpha_{1} h+\cdots+\alpha_{p} h^{p}\right) d h \\
=\alpha_{0} h+\frac{\alpha_{1} h^{2}}{2}+\cdots+\left.\frac{\alpha_{p} h^{(p+1)}}{p+1}\right|_{t_{a}} ^{t_{b}} \\
=\left[\alpha_{0} t_{b}+\alpha_{1} \frac{t_{b}{ }^{2}}{2}+\ldots+\alpha_{p} \frac{t_{b}^{p+1}}{p+1}\right]-\left[\alpha_{0} t_{a}+\alpha_{1} \frac{t_{a}^{2}}{2}+\ldots+\alpha_{p} \frac{t_{a}^{p+1}}{p+1}\right]
\end{gathered}
$$

Where $t_{a, b}=\frac{a, b-\bar{t}}{24}, \bar{t}=78.9$ and $p$ was the polynomial order. For sequence $1, a=0$

and $b \in[1,244]$, whereas for sequence $2, a \in[0,220]$ and $b=244$. After $244 \mathrm{~h}$, levels of

OsHV-1 DNA and Vibrio spp. concentration in the seawater were considered to as null.

regression models. For the sequence 1, the relationship between the logit of mortality and

CEIs appeared quadratic-plateau, so that the model was:

$$
\operatorname{logit}(p)=\left\{\begin{array}{c}
\delta_{0}+\delta_{1} x+\delta_{2} x^{2} \text { if } x<x_{0} \\
\delta_{0}+\delta_{1} x_{0}+\delta_{2} x_{0}^{2} \text { if } x \geq x_{0}
\end{array}\right.
$$

255 Finally, the model accuracy was measured by the area under the curve ROC (receiver operating characteristic). An area of 1 represents a perfect test whereas an area of 0.5

257 represents a worthless test.

258 Statistical analyses were conducted using the SAS software package (9.4. SAS 259 Institute, NC). A significance threshold of 5\% was adopted for all statistical tests.

\section{RESULTS}


In our study, recipient oysters were transferred from a tank containing naturally

263 infected oysters (pathogen-exposure tank) toward individual safe tanks (sequence 1) or

264 from safe tanks toward the pathogen-exposure tank (sequence 2) at 16 time points from 265 the beginning to the end of the experiment $(220 \mathrm{~h})$. Level of OsHV-1 DNA and 266 concentrations of cultivable Vibrio spp. were monitored in the pathogen-exposure tank, 267 and the cumulative exposure indexes of the recipient oysters to these microorganisms were estimated. Mortalities of the recipients were recorded at the end of the experiment (391 h) and the relationship between mortality and the exposure indexes were tested. At the beginning of the cohabitation phase, no mortality was observed on donors and recipients. First mortalities were observed after $12 \mathrm{~h}$ in donors (2.3\% mortality) and after $96 \mathrm{~h}$ in recipients in the pathogen-exposure tank (Figure A1). At the end of the experiment (391 h), mortality in donors was $51.7 \%$ and $26.4 \%$ in recipients that were left undisturbed in the pathogen-exposure tank (Figures 2A and A1). No mortality was recorded in the control tank but trace level of OsHV-1 DNA and low concentration of Vibrio spp. were occasionally detected in the surrounding seawater (Figures A1 and A2). In oysters from sequence 1 , mortality of recipients increased with time spent in the pathogen-exposure tank following an exponential growth pattern up until reaching a plateau at $21.1 \%$ (Figure 2A). After only $1.5 \mathrm{~h}$ spent in the pathogen-exposure tank, 280 recipients exhibited $2.7 \%$ final cumulative mortality in the safe tank. Mortality reached 281 the plateau value after $135 \mathrm{~h}(5.6 \mathrm{~d})$ of exposure in the pathogen-exposure tank. The level of OsHV-1 DNA in recently dead oysters collected after $136 \mathrm{~h}$ was $1.2 \times 10^{8} \mathrm{cp} \mathrm{mg}^{-1}$ tissues 283 (mean of 5 samples $\pm 5.2 \times 10^{6}$ ). In oysters from sequence 2 , mortality of recipients decreased with time spent in the safe tanks following an exponential decay pattern (Figure 2A). Mortality curves of recipients from sequences 1 and 2 crossed at $x=54.9 \mathrm{~h}$ and $\mathrm{y}=12.0 \%$ mortality. This means 
that oysters that spent the first 55 hours in the pathogen-exposure tank exhibited as much mortality as those which spent the next 165 hours. No mortality was observed in the recipients transferred in the pathogen-exposure tank $172 \mathrm{~h}$ after the beginning of the experiment. However, few mortalities (1-4\%) were reported in the subsequent transfers.

291 The regression model predicts that mortality would plateau in recipients transferred 508 $292 \mathrm{~h}(21 \mathrm{~d})$ after the start of the cohabitation.

At the beginning of the experiment, OsHV-1 DNA was not detected in the seawater of the pathogen-exposure tank (Figure 2B). After only $1.5 \mathrm{~h}$ of cohabitation, high level of OsHV-1 DNA $\left(4 \times 10^{6} \mathrm{cp} \mathrm{mL}-1\right)$ was detected in the seawater and remained between 4 $\times 10^{6}$ to $4 \times 10^{7} \mathrm{cp} \mathrm{mL}-1$ until $220 \mathrm{~h}$. Virus DNA was not detected afterwards. A fourthorder polynomial was fitted level of OsHV-1 DNA and time (Figure 2B). This model indicates that OsHV-1 DNA in the seawater peaked at $47.9 \mathrm{~h}$.

The Vibrio spp. concentration in the seawater of the pathogen-exposure tank increased from 20 to $310 \mathrm{cfu} \mathrm{mL}^{-1}$ after only one hour of cohabitation, increased up until reaching a maximum after $44 \mathrm{~h}\left(1650 \mathrm{cfu} \mathrm{mL}^{-1}\right)$ and gradually decreased to $0 \mathrm{cfu} \mathrm{mL}^{-1}$ after $172 \mathrm{~h}$ (Figure 2C). A third-order polynomial was fitted Vibrio spp. concentration and time. According to this model, Vibrio spp. concentration peaked at $49.6 \mathrm{~h}$.

The cumulative exposure indexes (CEIs) to OsHV-1 and Vibrio spp. that reflect both the concentration and the duration of exposure to these microorganisms increased with time spent in the pathogen-exposure tank (Figure 3).

308 (Figure 4). For the recipients in sequence 1, the relationship between mortality and CEIs 309 was quadratic, suggesting that mortality plateaued and then reached a threshold CEI. 310 However, for the recipients in sequence 2, the quadratic component was not significant, 311 so that the relationship between mortality and CEIs was considered linear (Figure 3). In 

unit in CEI of OsHV-1 and Vibrio spp., respectively. The area under the curve ROC were

314 respectively 0.681 for sequence 1 and 0.720 for sequence 2 for both CEIs, so that the 315 model accuracy was fair.

\section{DISCUSSION}

Although the method of infection used in the present study has been widely applied during the last five years, the dynamics of disease transmission through the water column remains to be finely characterized. We addressed this issue in the present work. We provided temporal dynamics of OsHV-1 DNA and Vibrio spp. concentrations in the seawater in relation with mortality of "recipient" oysters that were placed in cohabitation with "donor" oysters which were naturally infected in the field. As it was recently demonstrated that infection by OsHV-1 is the first event that occurs during infectious process followed by a secondary infection by bacteria including vibrios (de Lorgeril et al. $2018 \mathrm{~b}$ ), we followed the concentrations of these both pathogens in water tanks. We found that levels of OsHV-1 DNA and Vibrio spp. concentration in the seawater of the pathogenexposure tank peaked at almost the same time ( $48 \mathrm{~h}$ and $50 \mathrm{~h}$ respectively). associated with the cumulative exposure to both OsHV-1 and Vibrio spp. In line with this, mortality risk of recipients cohabited with donors increases with the biomass of infected oysters and decreases with seawater renewal, two parameters that probably influence 333 pathogen concentrations in the surrounding seawater (Petton et al. 2015a). Also, 334 mortality risk of oysters injected with a viral suspension increases with concentration of 335 viral particles (Paul-Pont et al. 2015, Segarra et al. 2016). Finally, non-lethal infection of oysters in the field were associated with the dilution of viral particles below a threshold 
value under which no mortality occurs (Pernet et al. 2018). All together, these results showed a clear relationship between mortality of recipients and pathogens concentration 339 in the seawater.

It took only $1.5 \mathrm{~h}$ of cohabitation with donors to detect OsHV-1 DNA in the surrounding seawater and to observe mortality in recipients at the end of the experiment

342 (16 d, sequence 1). This result suggests that the transmission is very rapid. This could 343 probably explain why the disease spread so fast when the infectious conditions are in 344 place in farms. From an experimental standpoint, studies dedicated to the investigation 345 of the host response to the disease should focus on early times after exposure. Until now, 346 the earliest samples that were analysed were collected 6 hours after the cohabitation 347 starts (de Lorgeril et al. 2018b).

348 Mortality of recipients plateaued after 135 hours of cohabitation (5.6 d) with 349 donors, i.e. $39 \mathrm{~h}$ after onset of the first dead recipient. In previous experiments, the 350 cohabitation phase of donors and recipients lasted until appearance of the first dead 351 recipient which generally occurred after 4 days (Petton et al. 2013, Lassudrie et al. 2015, 352 Pernet et al. 2015, Petton et al. 2015a, Petton et al. 2015b, Fuhrmann et al. 2016). 353 However, to reach maximum mortality in recipients, it is necessary to continue the 354 cohabitation 1 to $2 \mathrm{~d}$ more. Then, the donors can be removed instead of leaving them 355 dying, decomposing, mineralising and therefore, altering the biogeochemical conditions 356 in the experimental tanks (Richard et al. 2017). This would avoid some confounding 357 effects during experiments.

358 The relationship between recipient mortality and cohabitation time with donors 359 from both sequences 1 and 2 suggests that infectivity in the pathogen-exposure tank 360 decreased with time. For instance, oysters that spent the first $55 \mathrm{~h}$ in the pathogen361 exposure tank exhibited as much mortality as those who spent the next $165 \mathrm{~h}$, and almost 
no mortality $(0-4 \%)$ was observed in oysters transferred in the pathogen-exposure tank after $172 \mathrm{~h}$. This agrees with the fact that levels of OsHV-1 DNA and Vibrio spp. concentration in the seawater peaked after $c a .48 \mathrm{~h}$ and decreased to zero after $172-220 \mathrm{~h}$. Although laboratory experiments do not fully reproduce field conditions, the temporal dynamics of oyster mortality in the laboratory were similar to those occurring in the field (de Lorgeril et al. 2018b). Also, cumulative final mortality was only $26 \%$ in undisturbed recipients, reflecting a low pathogen-exposure that is typical of the fall in the Thau lagoon (Pernet et al. 2012). Finally, concentrations of OsHV-1 DNA in the seawater were slightly higher than those reported in laboratory conditions by Schikorski et al. (2011) and Paul-Pont et al. (2015). To our knowledge, there are no data available on the temporal dynamics of OsHV-1 concentration in seawater in the field to which we can compare our laboratory data.

To conclude, we found that $i$ ) OsHV-1 and Vibrio spp. concentrations in the seawater showed clear temporal dynamics, ii) mortality of recipients was associated with increasing cohabitation time with donors and reflect the cumulative exposure to OsHV-1 and Vibrio spp., iii) after only $1.5 \mathrm{~h}$ of cohabitation with donors, OsHV-1 DNA was detected at high concentration in seawater and mortality in recipients occurred, iv) mortality of recipients plateaued after 5-6 d of cohabitation with donors following by 1-2 $d$ the first dead donor and $v$ ) infectivity in the pathogen-exposure tank decreased with time up to values close to zero after $172 \mathrm{~h}$. Although this experiment had not been replicated in time, the mortality dynamics of the recipients observed here was consistent with all the others published in the similar conditions. Therefore, the fine-scale dynamics of mortality and OsHV-1 and Vibrio spp. concentration in seawater reported here can be generalized to other experiments conducted in similar conditions. 
The authors are very grateful to J. Le Grand, D. Ratiskol, M. Riobé, M. Huber and M.

Nourry for animal production and maintenance, F. Le Roux for critical comments on the

manuscript and J.-M. Escoubas for providing dual RNA-seq data allowing identification of

OsHV-1 $\mu$ Var. This study was supported by the French Research Agency ANR (ANR-12-

AGRO-0001 GIGASSAT, ANR-13-ADAP-0007-01 OPOPOP, ANR-14-CE19-0023 DECIPHER,

ANR-16-CE32-0008-02 REVENGE). BP conceived and performed experiment, GD, FP and

MAB conducted statistical analyses, BP, MAB and FP drafted the manuscript. All authors

contribute to the manuscript and approved it.

\section{REFERENCES}

AHAW EPAHW (2015) Oyster mortality EFSA Panel on Animal Health and Welfare (AHAW). Efsa Journal 13

Azema P, Travers MA, Benabdelmouna A, Degremont L (2016) Single or dual experimental infections with Vibrio aestuarianus and OsHV-1 in diploid and triploid Crassostrea gigas at the spat, juvenile and adult stages. J Invertebr Pathol

Barbosa Solomieu V, Renault T, Travers M-A (2015) Mass mortality in bivalves and the intricate case of the Pacific oyster, Crassostrea gigas. J Invertebr Pathol 131:2-10

Bruto M, James A, Petton B, Labreuche Y, Chenivesse S, Alunno-Bruscia M, Polz MF, Le Roux F (2017) Vibrio crassostreae, a benign oyster colonizer turned into a pathogen after plasmid acquisition. ISME J 11:1043-1052

Burioli EAV, Prearo M, Houssin M (2017) Complete genome sequence of Ostreid herpesvirus type $1 \mu$ Var isolated during mortality events in the Pacific oyster Crassostrea gigas in France and Ireland. Virology 509:239-251

de Lorgeril J, Escoubas J-M, Loubiere V, Pernet F, Le Gall P, Vergnes A, Aujoulat F, Jeannot J-L, Jumas-Bilak E, Got P, Gueguen Y, Destoumieux-Garzón D, Bachère E (2018a) Inefficient immune response is associated with microbial permissiveness 
in juvenile oysters affected by mass mortalities on field. Fish Shellfish Immunol $77: 156-163$

de Lorgeril J, Lucasson A, Petton B, Toulza E, Montagnani C, Clerissi C, Vidal-Dupiol J, Chaparro C, Galinier R, Escoubas J-M, Haffner P, Dégremont L, Charrière GM, Lafont M, Delort A, Vergnes A, Chiarello M, Faury N, Rubio T, Leroy MA, Pérignon A, Régler

Fuhrmann M, Delisle L, Petton B, Corporeau C, Pernet F (2018) Metabolism of the Pacific D, Morga B, Alunno-Bruscia M, Boudry P, Le Roux F, Destoumieux-Garzón D, Gueguen Y, Mitta G (2018b) Immune-suppression by OsHV-1 viral infection causes fatal bacteraemia in Pacific oysters. Nat Commun 9:4215 oyster, Crassostrea gigas, is influenced by salinity and modulates survival to the Ostreid herpesvirus OsHV-1. Biol Open 7:10

Fuhrmann M, Petton B, Quillien V, Faury N, Morga B, Pernet F (2016) Salinity influences disease-induced mortality of the oyster Crassostrea gigas and infectivity of the ostreid herpesvirus 1 (OsHV-1). Aquaculture Env Interact 8:543-552

Fuhrmann M, Richard G, Quere C, Petton B, Pernet F (2019) Low pH reduced survival of the oyster Crassostrea gigas exposed to the Ostreid herpesvirus 1 by altering the metabolic response of the host. Aquaculture 503:167-174

Jenkins C, Hick P, Gabor M, Spiers Z, Fell SA, Gu X, Read A, Go J, Dove M, O'Connor W, Kirkland PD, Frances J (2013) Identification and characterisation of an ostreid herpesvirus-1 microvariant (OsHV-1 mu-var) in Crassostrea gigas (Pacific oysters) in Australia. Dis Aquat Org 105:109-126

Jones B, Kenward MG (2014) Design and analysis of cross-over trials, Vol. Chapman and Hall/CRC

Lassudrie M, Soudant P, Nicolas J-L, Fabioux C, Lambert C, Miner P, Le Grand J, Petton B, Hégaret H (2015) Interaction between toxic dinoflagellate Alexandrium catenella exposure and disease associated with herpesvirus OsHV-1 $\mu$ Var in Pacific oyster spat Crassostrea gigas. Harmful Algae 45:53-61

Le Roux F, Wegner KM, Polz MF (2016) Oysters and Vibrios as a Model for Disease Dynamics in Wild Animals. Trends Microbiol 24:568-580

Lemire A, Goudenege D, Versigny T, Petton B, Calteau A, Labreuche Y, Le Roux F (2015) Populations, not clones, are the unit of vibrio pathogenesis in naturally infected oysters. ISME J 9:1523-1531 
Lucasson A, Petton B, Clerissi C, Toulza E, Escoubas J-M, Haffner H, Dégremont L, Gueguen Y, de Lorgeril J, Mitta M (in prep) The mechanism of the polymicrobial disease affecting Pacific oyster juveniles is conserved between oyster genotypes and infectious environments

Lynch SA, Carlsson J, Reilly A0, Cotter E, Culloty SC (2012) A previously undescribed ostreid herpes virus 1 (OsHV-1) genotype detected in the Pacific oyster, Crassostrea gigas, in Ireland. Parasitology 139:1526-1532

Martenot C, Oden E, Travaille E, Malas J-P, Houssin M (2011) Detection of different variants of Ostreid Herpesvirus 1 in the Pacific oyster, Crassostrea gigas between 2008 and 2010. Virus Res 160:25-31

Mortensen S, Strand Å, Bodvin T, Alfjorden A, Skår CK, Jelmert A, Aspán A, Sælemyr L, Naustvoll LJ, Albretsen J (2016) Summer mortalities and detection of ostreid herpesvirus microvariant in Pacific oyster Crassostrea gigas in Sweden and Norway. Dis Aquat Org 117:171-176

Oehlert GW (1992) A Note on the Delta Method. The American Statistician 46:27-29

Paul-Pont I, Evans O, Dhand NK, Whittington RJ (2015) Experimental infections of Pacific oyster Crassostrea gigas using the Australian ostreid herpesvirus-1 (OsHV1) $\mu$ Var strain. Dis Aquat Org 113:137-147

Pepin JF, Riou A, Renault T (2008) Rapid and sensitive detection of ostreid herpesvirus 1 in oyster samples by real-time PCR. J Virol Methods 149:269-276

Pernet F, Barret J, Gall PL, Corporeau C, Dégremont L, Lagarde F, Pépin J-F, Keck N (2012) Mass mortalities of Pacific oysters Crassostrea gigas reflect infectious diseases and vary with farming practises in the Thau lagoon. Aquaculture Env Interact 2:215-237

Pernet F, Fuhrmann M, Petton B, Mazurié J, Bouget J-F, Fleury E, Daigle G, Gernez P (2018) Determination of risk factors for herpesvirus outbreak in oysters using a broad-scale spatial epidemiology framework. Sci Rep 8

Pernet F, Lupo C, Bacher C, Whittington RJ (2016) Infectious diseases in oyster aquaculture require a new integrated approach. Philos Trans R Soc Lond B Biol Sci $371: 20150213$

Pernet F, Tamayo D, Petton B (2015) Influence of low temperatures on the survival of the Pacific oyster (Crassostrea gigas) infected with ostreid herpes virus type 1. Aquaculture 445:57-62 
Petton B, Boudry P, Alunno-Bruscia M, Pernet F (2015a) Factors influencing diseaseinduced mortality of Pacific oysters Crassostrea gigas. Aquaculture Env Interact 6:205-222

Petton B, Bruto M, James A, Labreuche Y, Alunno Bruscia M, Le Roux F (2015b) Crassostrea gigas mortality in France: the usual suspect, a herpes virus, may not be the killer in this polymicrobial opportunistic disease. Front Microbiol 6

Petton B, Pernet F, Robert R, Boudry P (2013) Temperature influence on pathogen transmission and subsequent mortalities in juvenile Pacific oysters Crassostrea gigas. Aquaculture Env Interact 3:257-273

Renault T, Moreau P, Faury N, Pepin J-F, Segarra A, Webb S (2012) Analysis of clinical ostreid herpesvirus 1 (Malacoherpesviridae) specimens by sequencing amplified fragments from three virus genome areas. J Virol 86(10): 5942-5947.

Richard M, Bourreau J, Montagnani C, Ouisse V, Le Gall P, Fortune M, Munaron D, Messiaen G, Callier M, d'Orbcastel ER (2017) Influence of OSHV-1 oyster mortality episode on dissolved inorganic fluxes: An ex situ experiment at the individual scale. Aquaculture 475:40-51

Schikorski D, Faury N, Pepin JF, Saulnier D, Tourbiez D, Renault T (2011) Experimental ostreid herpesvirus 1 infection of the Pacific oyster Crassostrea gigas: Kinetics of virus DNA detection by q-PCR in seawater and in oyster samples. Virus Res $155: 28-34$

Segarra A, Baillon L, Faury N, Tourbiez D, Renault T (2016) Detection and distribution of ostreid herpesvirus 1 in experimentally infected Pacific oyster spat. J Invertebr Pathol 133:59-65

Segarra A, Pepin JF, Arzul I, Morga B, Faury N, Renault T (2010) Detection and description of a particular Ostreid herpesvirus 1 genotype associated with massive mortality outbreaks of Pacific oysters, Crassostrea gigas, in France in 2008. Virus Res 153:92-99

Tamayo D, Corporeau C, Petton B, Quere C, Pernet F (2014) Physiological changes in Pacific oyster Crassostrea gigas exposed to the herpesvirus OsHV-1 $\mu$ Var. Aquaculture 432:304-310

Vacek PM (1997) Assessing the effect of intensity when exposure varies over time. Stat Med 16:505-513 
512 Webb SC, Fidler A, Renault T (2007) Primers for PCR-based detection of ostreid herpes

513 virus-1 (OsHV-1): Application in a survey of New Zealand molluscs. Aquaculture $514 \quad 272: 126-139$

515 
517 FIG. 1. (1) Families of oysters (15) from 5 origins were produced in the laboratory and

518 (2) transferred in the Thau lagoon during the infectious period for 17 days and (3) used

519 as pathogen donors in the laboratory. The remaining part of the mixed oyster population

520 was left undisturbed at the facility to be used as uninfected control. A batch of specific-

521 pathogen free oysters was displayed in 51 mesh-bags (100 individuals per bag) and kept

522 under biosecured conditions. Seventeen bags were placed in the pathogen-exposure tank

523 in cohabitation with the donors and they were used as pathogen recipients. Seventeen

524 other bags were placed in individual flow through 50-L tanks referred to as safe tanks.

525 Then, each bag was either transferred from the pathogen-exposure towards safe tanks

526 (sequence 1) or from safe tanks towards the pathogen-exposure tank (sequence 2). These

527 permutations were conducted 16 times in the time. Two oyster bags were left

528 undisturbed in the pathogen-exposure tank and in one safe tank. The remaining 17 bags

529 of SPF oysters were displayed in the control tank. Live and dead recipients were counted

530 in each bag at the end of the experiment.

531 FIG 2. Mortality of recipient oysters at the end of the experiment ( $391 \mathrm{~h}$ ) according to the

532 time of transfer (A). Oysters were transferred from a tank containing infected oysters

533 (pathogen-exposure tank) toward individual safe tanks (sequence 1) or from safe tanks

534 toward the pathogen-exposure tank (sequence 2). Black lines indicate regression model

535 fitted to the data and grey lines show the 95\% confidence interval. Dynamics of OsHV-1

536 DNA (B) and Vibrio spp. concentration (C) in the seawater of the pathogen-exposure tank

537 as a function of time. Dotted lines indicate the time.

538 FIG. 3. Cumulative exposure index of oysters (see eq. 10) transferred from a tank 539 containing infected oysters (pathogen-exposure tank) toward individual safe tanks 
540 (sequence 1) or from safe tanks toward the pathogen-exposure tank (sequence 2)

541 calculated for OsHV-1 DNA and Vibrio spp. concentrations.

542 FIG. 4. Relationship between mortality and cumulative exposure index to OsHV-1 and

543 Vibrio spp. for oysters transferred from a tank containing infected oysters (pathogen-

544 exposure tank) toward individual safe tanks (sequence 1, left) or from safe tanks toward

545 the pathogen-exposure tank (sequence 2, right). Dotted lines indicate the value of $\mathrm{x}_{0}$,

546 beyond which the values of y are constant (plateau). 
(1) Laboratory $\begin{aligned} & \text { oyster production } \\ & \text { \& maintenance }\end{aligned}$

2 Thau lagoon $\begin{aligned} & \text { Field infection of } \\ & \text { oysters (donors) }\end{aligned}$

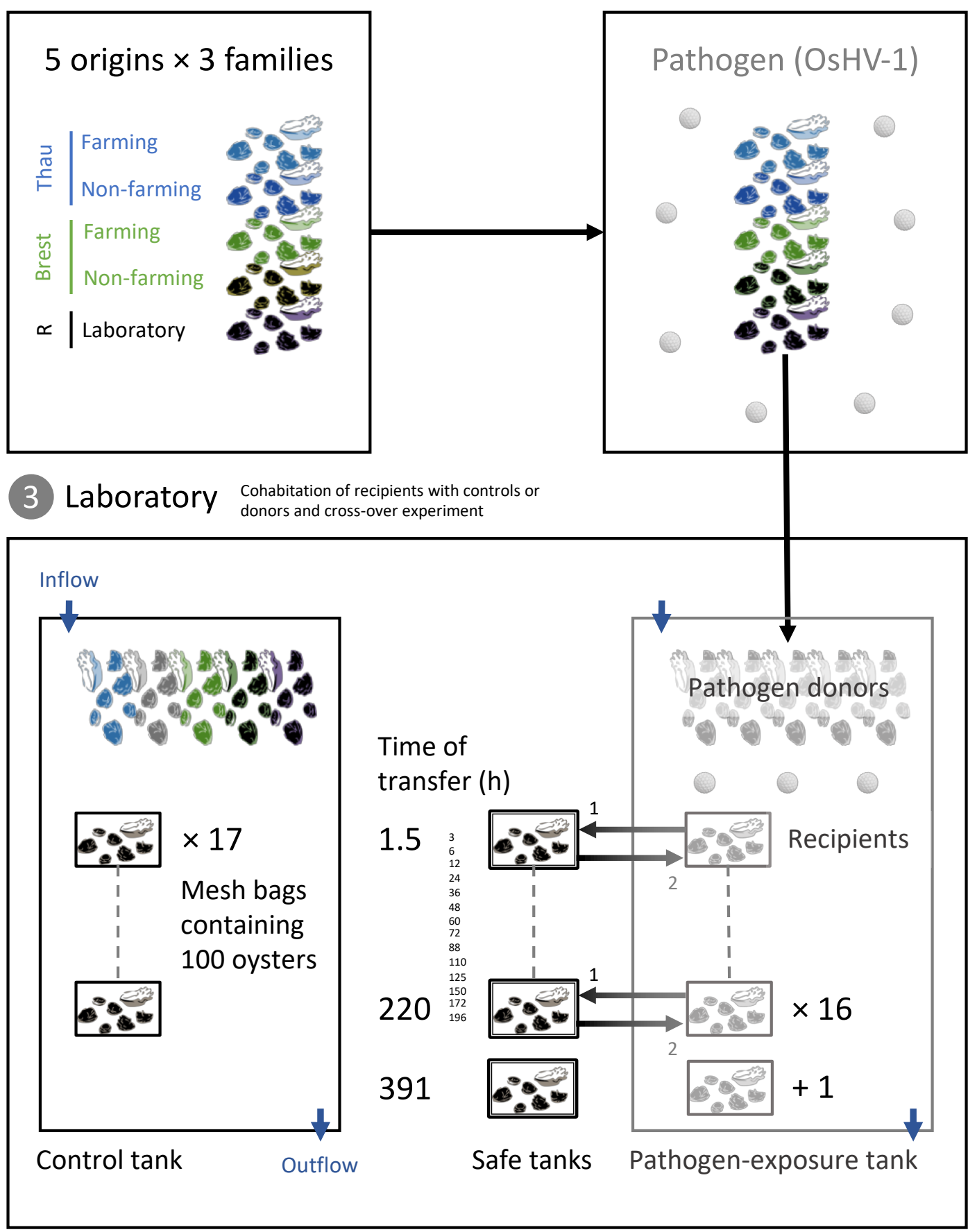



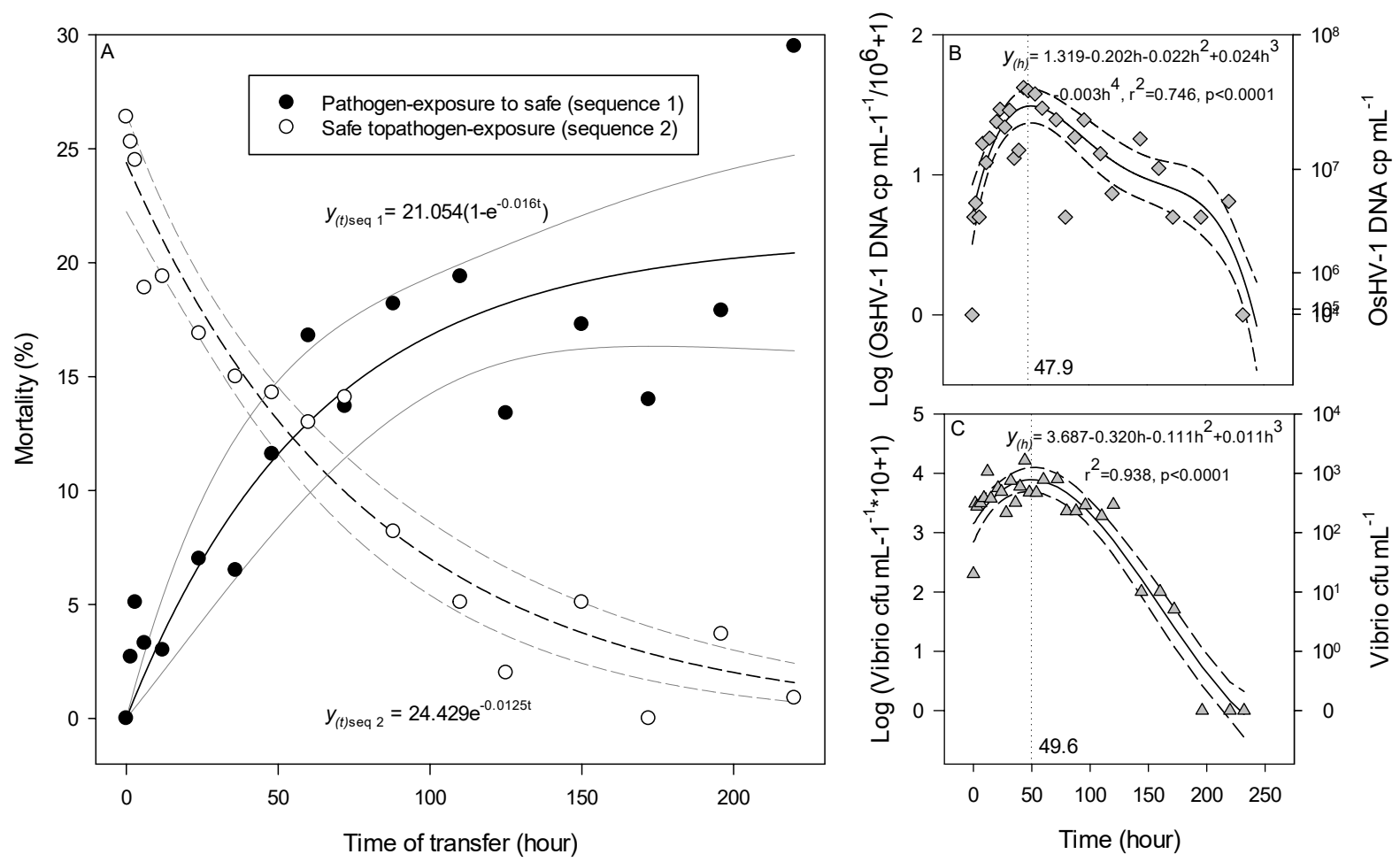
FIGURE 3.

Pathogen-exposure to safe (sequence 1)

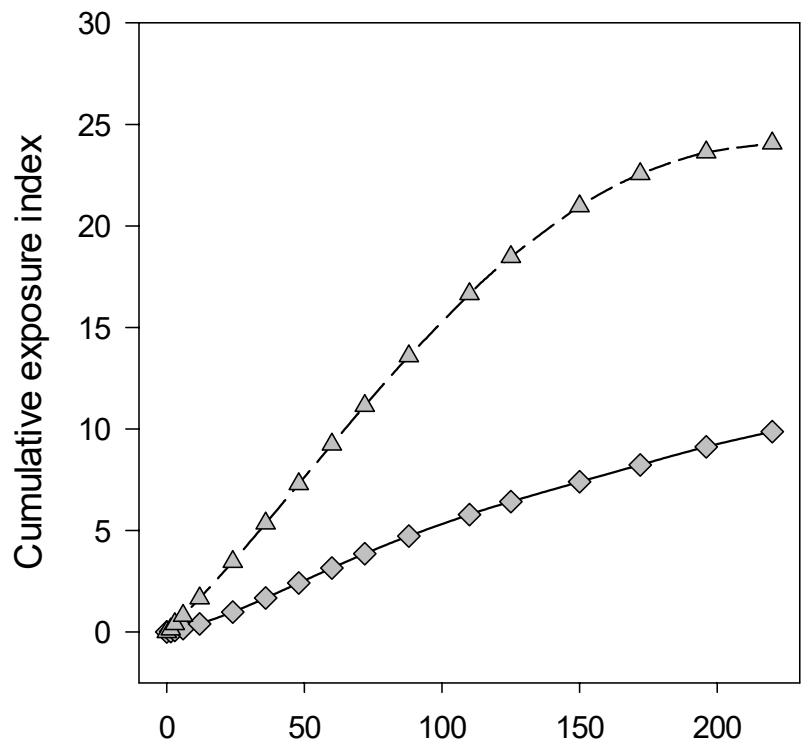

Safe to pathogen-exposure

(sequence 2)

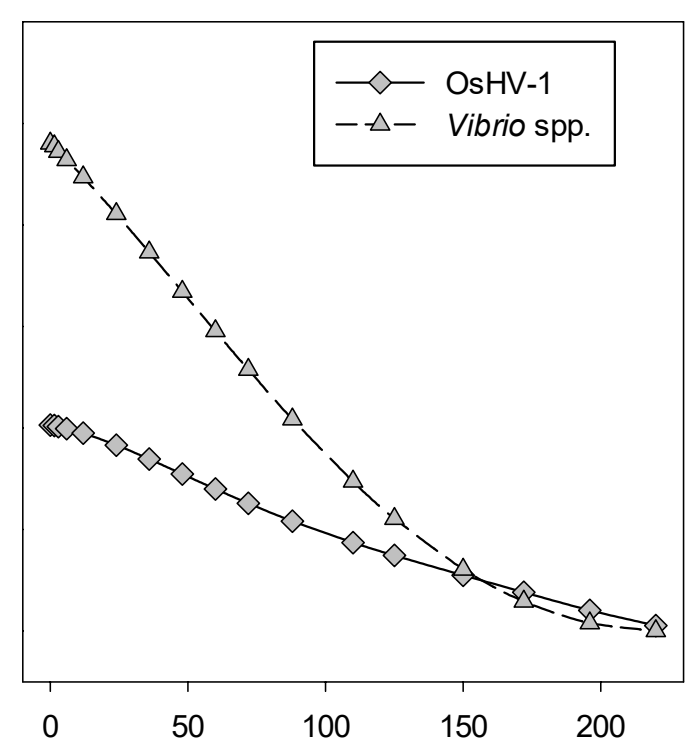

554

Time of transfer (hour) 
556

Pathogen-exposure to safe (sequence 1)

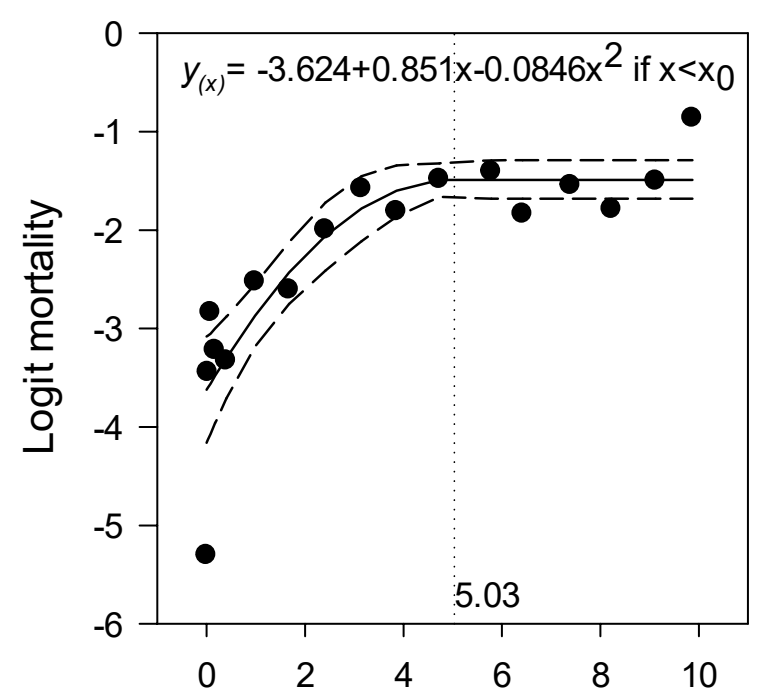

Safe to pathogen-exposure (sequence 2)

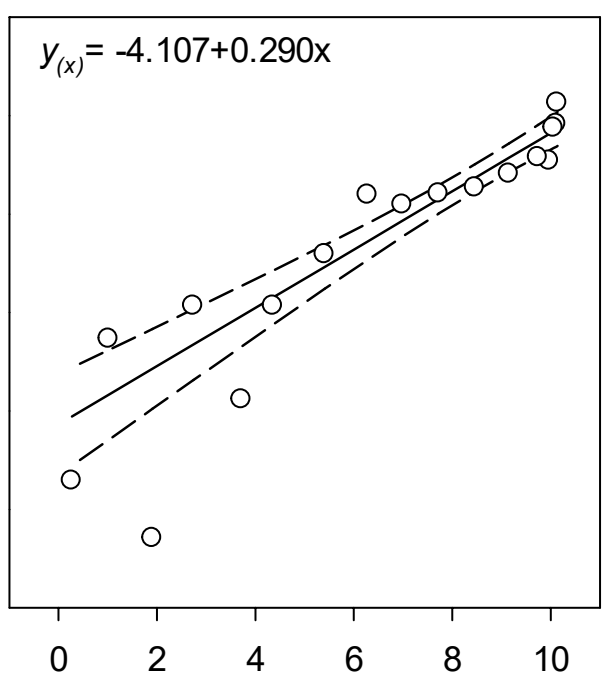

Cumulative exposure index OsHV-1
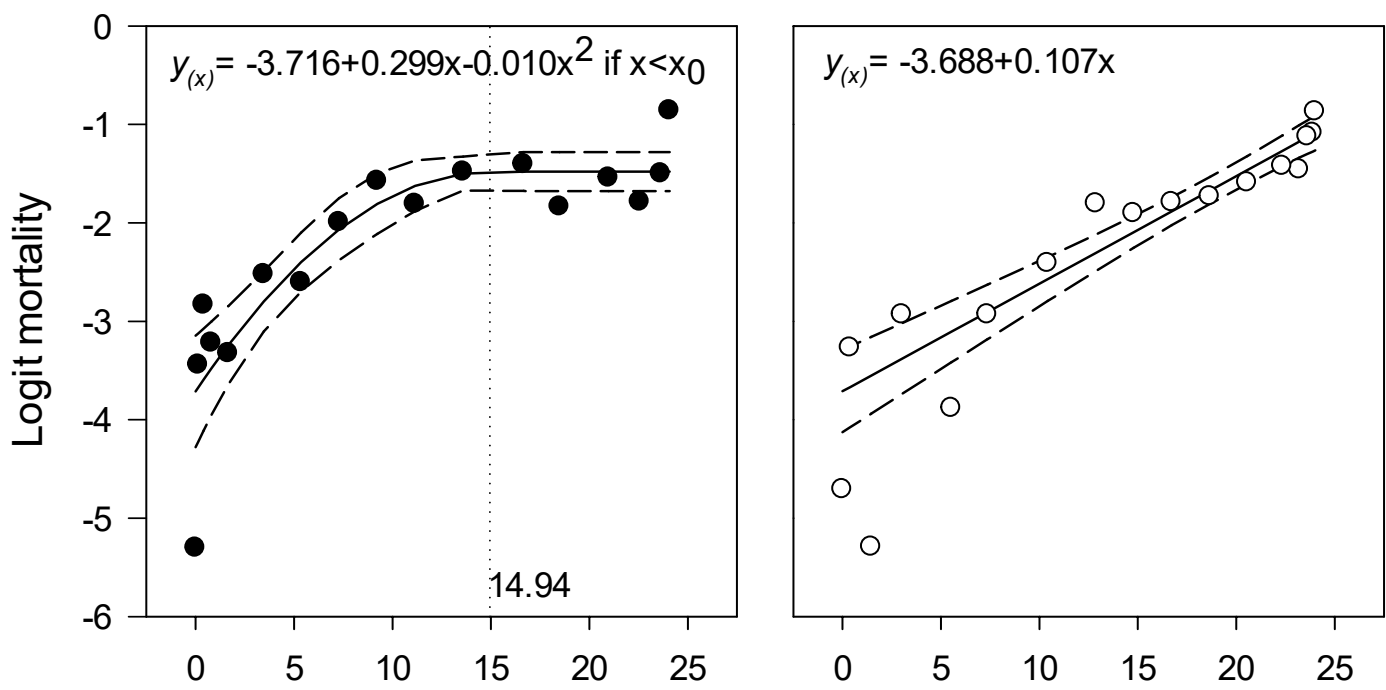

Cumulative exposure index Vibrio spp. 


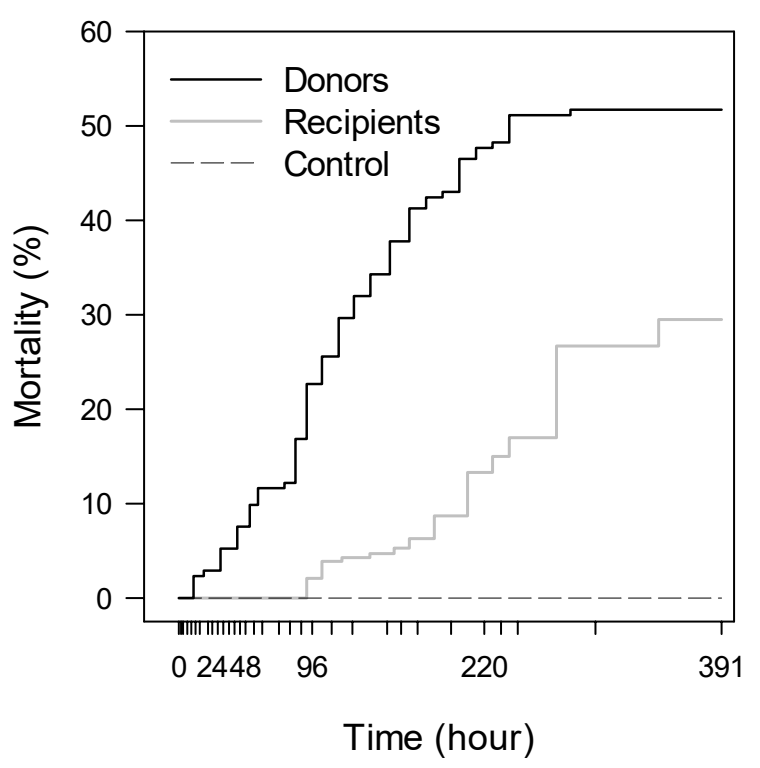

26 FIGURE A1. Dynamics of mortality in donors and recipients in the pathogen-exposure 27 tank and in uninfected oysters (control). For each time between 1.5 and $220 \mathrm{~h}$, recipient mortality was measured in the oyster bag that was transferred to the safe tanks. As a result, these mortality measures were independent of each other. After 220 hours, the donors were removed and there were no more transfers. Between $220 \mathrm{~h}$ and $391 \mathrm{~h}$, recipient mortality was estimated on the oyster bag which remained in the pathogenexposure tank.

Control oysters showed no mortality (Figure A1) but trace level of OsHV-1 DNA and low concentration of Vibrio spp. were occasionally detected in the surrounding seawater (Figure A2). Although these control oysters may not have been SPF during the entire duration of the experiment, absence of mortality suggest that they were healthy, and only

37 the pathogen donors and recipients were considered hereafter. 

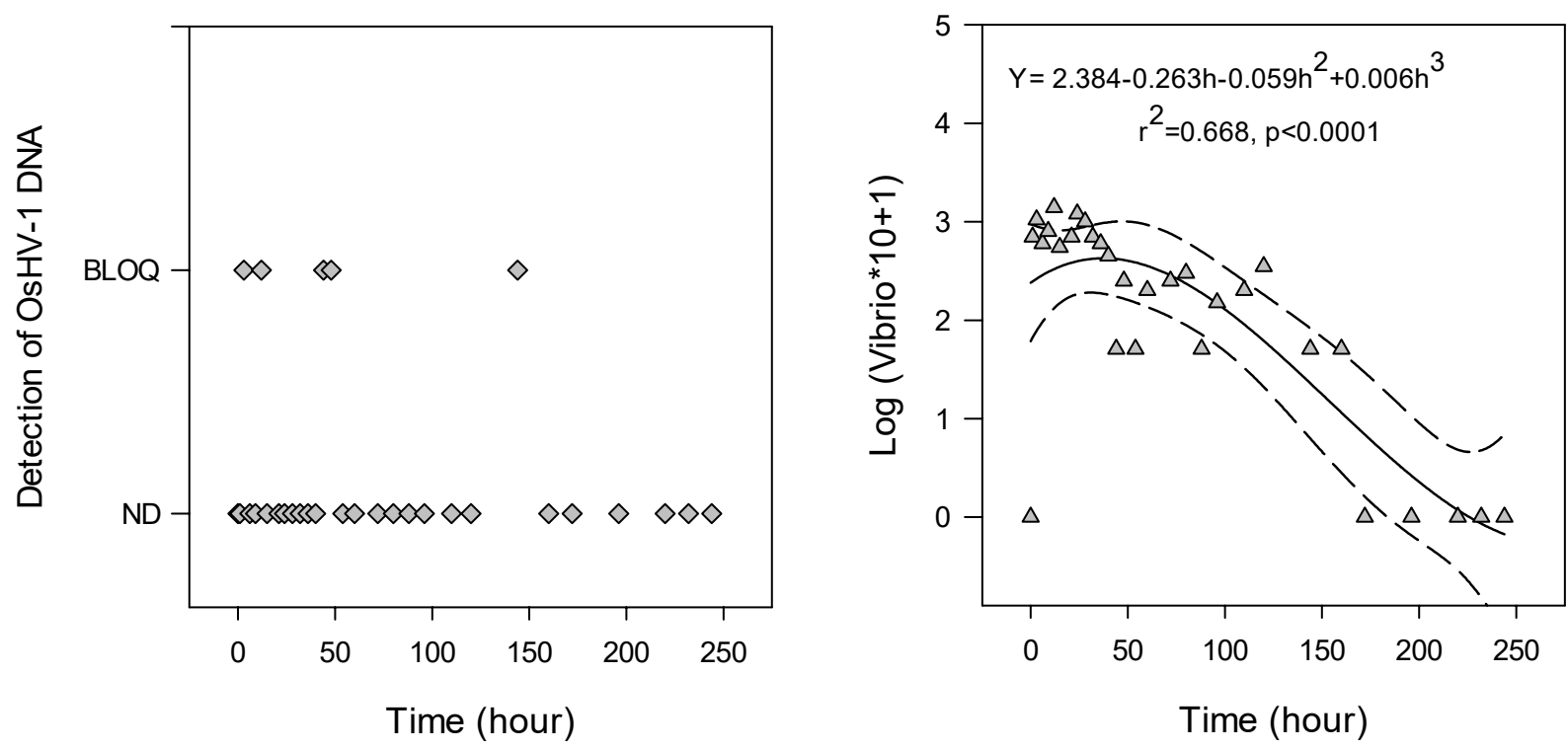

40 FIGURE A2. Dynamics of OsHV-1 DNA detection and Vibrio spp. concentration in the

41 seawater of the control tank as a function of time. Abbreviations: ND, not detected, BLOQ,

42 detected but below the level of quantification $\left(<10 \mathrm{cp} \mu \mathrm{L}^{-1}\right)$.

43 